\title{
Assessment of Flexural Strength and Color Alteration of Heat-Polymerized Acrylic Resins After Simulated Use of Denture Cleansers
}

\author{
Sandra SATO \\ Márcia Rosa Sobreira CAVALCANTE \\ Iara Augusta ORSI \\ Helena de Freitas Oliveira PARANHOS \\ Osvaldo ZANIQUELLI \\ Department of Dental Materials and Prosthodontics, Faculty of Dentistry of Ribeirão Preto, \\ University of São Paulo, Ribeirão Preto, SP, Brazil
}

\begin{abstract}
The purpose of this study was to assess flexural strength and color alteration of acrylic resins immersed in denture cleansers for different periods of time. Rectangular specimens (65x10x3mm) made from three heat-polymerized acrylic resins (Lucitone 550, QC20 and Triplex) were assigned to three denture cleansers groups (Bony Plus, Corega Tabs and Efferdent Plus) and a control group (immersion in water). Soaking trials of $15 \mathrm{~min}$ and $8 \mathrm{~h}$ simulated 30 days of use. Flexural strength testing was carried out with 105 specimens on a universal testing machine. Color alterations were visually assessed by examination of photographs taken from 21 specimens. Flexural strength means (in MPa) were analyzed statistically by analysis of variance and Tukey's test at $5 \%$ significance level. There were significant differences $(\mathrm{p}<0.01)$ among the resins Lucitone (89.439 \pm 7.962$)$, Triplex (88.024 \pm 5.167$)$ and QC-20 (83.379 \pm 7.153 ). No significant differences ( $>>0.05$ ) were found either among the denture cleansers (Bony Plus $=87.693 \pm 6.943$; Corega Tabs $=86.955 \pm 7.114$; Efferdent Plus $=86.195 \pm 7.865$ and control $=86.536 \pm 7.012)$ or between the soaking periods $(15$ $\min =86.875 \pm 7.625$ and $8 \mathrm{~h}=87.432 \pm 7.355$ ) throughout the soaking cycles simulating 30 days of use. No color alterations were identified by visual examination. The findings of this study showed that chemical denture cleansers used according to the manufacturers' specifications did not cause flexural strength alterations or color changes in heat-polymerized acrylic resins submitted to soaking cycles that simulated 30 days of use.
\end{abstract}

Key Words: acrylic resin, complete denture, removable partial denture, polymethylmethacrylate, denture cleansers.

\section{INTRODUCTION}

Denture cleansing may be performed by a number of products, which are divided into two main classes: mechanical and chemical cleansers. An ideal denture cleanser should be simple to use, effectively remove organic and inorganic matter from denture surface, have bactericidal and fungicidal properties, and be compatible with all denture base materials (1). However, no currently available product fulfills all these requirements.

Chemical agents for denture cleansing have advantage of being simple to use, and several investigations have shown their efficacy in reducing biofilm formation in vitro (2-4) and in vivo (5-7). In vitro studies are useful because they help understanding the mode of action of denture cleansers under clinical conditions (8). Denture base materials can be damaged if the cleaning agents are not used according to the manufacturers' instructions. A frequently reported problem by chemical cleansers' users is a whitening effect on the denture base. Studies have been carried out to confirm this hypothesis and to investigate if other properties of denture base acrylic resins are also affected. The findings of several studies have shown that, indeed, the whitening effect and alterations in flexural strength were not related to the use of denture cleansers themselves, but to the high temperature of the water 
used to prepare the soaking solution (9-12). Ünlü et al. (13) observed a whitening effect in acrylic resins after 30 days of simulated use of chemical cleansers and measured color alterations with a reflectometer. However, the authors reported that significant differences were dependent on the acrylic resins and type of cleansing agents used. Physical properties were not evaluated in their study.

The purpose this study was to investigate whether heat-polymerized acrylic resins soaked in different denture cleansers would undergo flexural strength alterations or color changes when subjected to the recommended cleansing protocols for a simulated 30day period.

\section{MATERIAL AND METHODS}

Three heat-polymerized denture-base resins [Lucitone 550 - Dentsply, Petrópolis, RJ, Brazil; QC-20 - Dentsply; Triplex - Ivoclar, Schaan, Liechtenstein] and three denture cleansers [Bony Plus Express - Bonyf AG, Switzerland; Corega Tabs - Block Drug Company, Inc., Jersey City, NJ, USA; Efferdent Plus - Pfizer Inc., New York, NY, USA] were used in this study.

Dental stone moulds were prepared in dental flasks, each flask containing 3 Teflon ${ }^{\circledR}$ (DuPont, Wilmington, DE, USA) rectangular dies (each $65 \times 10$ x $3 \mathrm{~mm}$ ). The dies were coated with a thin layer of petroleum jelly before being invested. The flask base was prepared using $120 \mathrm{~g}$ of type III dental stone. Undercuts were placed in the stone for best retention of $80 \mathrm{~g}$ of type IV die stone, where the dies were invested. A new coat of petroleum jelly was applied before pouring the die stone and a final pouring of $300 \mathrm{~g}$ of dental stone was done. After set of the dental stone, the flasks were opened and the dies were removed from the investing material. The rectangular cavities obtained were used as moulds for preparation of acrylic resin specimens.

The resins were mixed according to the manufacturers' instructions. Powder to liquid ratios were $21.0 \mathrm{~g} / 10.0 \mathrm{~mL}$, for Lucitone 550; $23.0 \mathrm{~g} / 10.0$ $\mathrm{mL}$, for QC-20; and $23.4 \mathrm{~g} / 10.0 \mathrm{~mL}$, for Triplex. The monomer and polymer were mixed at once, allowed to reach a doughy stage and placed into the moulds. For Lucitone, the flasks were immersed in water at $73^{\circ} \mathrm{C}$ for $90 \mathrm{~min}$, raising the temperature to $100^{\circ} \mathrm{C}$ and maintaining the boiling for $30 \mathrm{~min}$. QC-20 specimens were polymerized according to the sequence named "cycle A" by the manufacturer: the flasks were immersed in boiling water, continued heating to regain boiling temperature and were left in boiling for $20 \mathrm{~min}$. Triplex specimens were polymerized by immersing the flasks in cold water, raising the temperature to $100^{\circ} \mathrm{C}$ and maintaining this temperature for $45 \mathrm{~min}$. Once the polymerization cycle was completed, the flask was allowed to slow cooling in a water bath at room temperature before deflasking. The acrylic specimens were trimmed with a tungsten bur and ground wet to the final dimensions with a series of silicon carbide abrasive papers (\#320, \#400, \#600, \#1000). Pumice and whiting were used for final polishing. The polished specimens were given an identifying number and six specimens of each resin were assigned to each experimental group.

The specimens were measured with a digital calliper (Model SC-6; Mitutoyo Sul America Ltda, Suzano, SP, Brazil) and the dimensions were recorded. The specimens were immersed in water at $50^{\circ} \mathrm{C}$ for 1 $\mathrm{h}$ for removal of residual monomer excess and stored in water at room temperature until the soaking trials were performed.

A total of 126 specimens were fabricated for this experiment, as follows: [(6 experimental samples X 3 heat-polymerized acrylic resins $\mathrm{X} 3$ denture cleansers $\mathrm{X}$ 2 soaking times $)+(6$ control samples $X 3$ heatpolymerized acrylic resins X 1 soaking solution (water)]. From these, 105 specimens were used for flexural strength testing and 21 specimens for assessment of color alteration. The following soaking trials were carried out: 1) $15 \mathrm{~min}, 3$ times a day for 10 days (simulating a 15-min daily soaking for 30 days); and 2) 8-h immersion periods, making up a total of $240 \mathrm{~h}$, with changes of the solution at every $8 \mathrm{~h}$ (simulating 30 overnight soaking periods). The denture cleansers (Bony Plus, Corega Tabs and Efferdent Plus) were dissolved in $250 \mathrm{~mL}$ of water at $45 \pm 2^{\circ} \mathrm{C}$. The control samples (6 of each resin) were stored in water at room temperature, the water being changed at every $8 \mathrm{~h}$.

\section{Flexural Strength Testing - Three-Point Loading}

Specimens were labeled on their bottom surface before testing, in such a way that the fractured portions could be reunited and examined after testing.

A three-point loading test was carried out using a universal testing machine (EMIC, São José dos 
Pinhais, PR, Brazil) at a crosshead speed of $1 \mathrm{~mm} / \mathrm{min}$ and distance between the specimen supports of $50 \mathrm{~mm}$. A $50 \mathrm{kgf}$ load cell was applied by a centrally located rod until fracture (Fig. 1). Flexural strength was calculated using the formula: $S=3 P L / 2 b d^{2}$, where $S$ is flexural strength, $P$ is the peak load applied, $L$ is the span length, $b$ is the specimen width and $d$ is the specimen thickness.

\section{Color Alteration}

One control specimen (stored in water) and one specimen of each resin brand immersed in the denture cleansers for $15 \mathrm{~min}$ and $8 \mathrm{~h}$ to simulate a 30-day soaking period, were put side by side and photographed (camera: Canon EOS-100S; lens: Canon 50mm f2.8 EF Macro - Canon, Tokyo, Japan). The photographs were examined independently by three examiners blinded to the resins, denture cleansers and immersion cycles to assess the occurrence of alterations in the resins' color.

Flexural strength results were analyzed statistically by analysis of variance and Tukey's test for multiple pairwise comparisons of the means. Significance level was set at 5\%. Statistical analyses were performed using the statistical package Number Cruncher Statistical System 2001 (NCSS Statistical Software, Kaysville, UT, USA).

\section{RESULTS}

Flexural strength results are given on Table 1. There were no significant differences ( $p>0.05$ ) after the

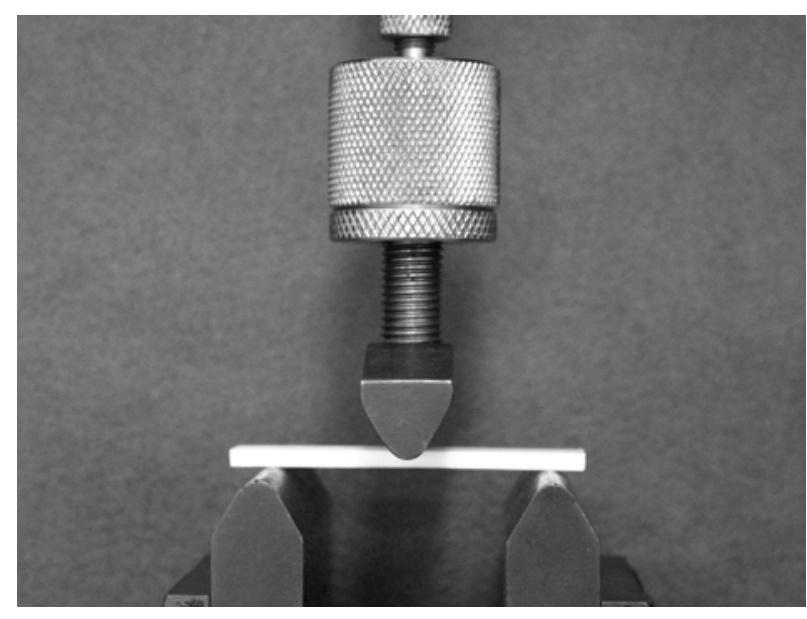

Figure 1. Specimen in place for the three-point loading flexural strength test

soaking trials regarding the use of different denture cleansers (mean \pm SD, in MPa): Bony Plus $=87.693 \pm$ 6.943; Corega Tabs = $86.955 \pm 7.114$; Efferdent Plus $=86.195 \pm 7.865$; and control $=86.536 \pm 7.012$ ). No differences were found ( $>0.05$ ) with respect to the soaking periods: $15 \mathrm{~min}=86.875 \pm 7.625$ and $8 \mathrm{~h}=$ $87.432 \pm 7.355$.

Statistically significant difference $(\mathrm{p}<0.01)$ occurred only when the acrylic resins were compared to each other. The Tukey's test (3.368) showed differences between the pairs QC-20 (83.379 \pm 7.153$)$ and Lucitone (89.439 \pm 7.962 ), and QC-20 and Triplex (88.024 \pm 5.167).

No clinically significant color alterations were observed on examination of the photographs.

Table 1. Effect on the flexural strength of denture base resins subjected to soaking in denture cleansers, for different periods of immersion, as analyzed by ANOVA.

\begin{tabular}{lcrrrr}
\hline Source of variation & DF & $\begin{array}{c}\text { Sum of } \\
\text { squares }\end{array}$ & $\begin{array}{c}\text { Mean } \\
\text { square }\end{array}$ & F-ratio & $\begin{array}{c}\text { Probability } \\
\text { level }\end{array}$ \\
\hline A: Resin & 2 & 904.455 & 452.228 & 8.72 & $0.000308^{*}$ \\
B: Denture cleanser & 2 & 50.501 & 25.251 & 0.49 & 0.615837 \\
C: Soaking time & 2 & 18.430 & 9.215 & 0.18 & 0.837427 \\
Interaction AxB & 4 & 92.944 & 23.236 & 0.45 & 0.773569 \\
Interaction AxC & 4 & 244.851 & 61.213 & 1.18 & 0.323534 \\
Interaction BxC & 4 & 43.271 & 10.818 & 0.21 & 0.933154 \\
Interaction AxBxC & 8 & 165.682 & 20.710 & 0.40 & 0.918727 \\
Error & 108 & 5600.227 & 51.854 & & \\
Total (Adjusted) & 134 & 7120.362 & & & \\
Total & 135 & & & & \\
\hline
\end{tabular}

* Source of variation significant at alpha $=0.05 . \mathrm{DF}$ : degrees of freedom. 


\section{DISCUSSION}

Its has been shown that brushing alone is not sufficient for good denture biofilm control and hence chemical cleansing is usually associated to mechanical cleansing to complement denture hygiene (8). Chemical denture cleansers have become increasingly more popular because of their advantageous ease of use, especially for those individuals with impaired manual dexterity. The most commonly used cleansers are represented by the group of alkaline peroxides (1). In the past, chemical cleansing was thought to possibly damage denture base materials, especially acrylic resins (14).

This study was undertaken to evaluate any mechanical or visual alterations in heat-polymerized denture base acrylic resins, after soaking in different alkaline peroxide cleansers for two periods of immersion, simulating a 30-day use.

It has been shown that immersion in certain cleansing solutions can affect the strength and the structure of denture base resins (10). If denture cleansers affect negatively the resins decreasing the strength, greater incidence of denture fractures might occur, both outside and inside the mouth. Outside the mouth, failure occurs due to impact if the denture is dropped. Inside the mouth, occlusal forces may also cause fracture. Midline fracture of the denture, for example, may occur as a consequence of flexural fatigue, resulting from cyclic deformation of the base during function. A supposed increased frequency of this type of failure, due to use of denture cleansers, can be demonstrated by the flexural strength testing. In this study, flexural strength results will be presented.

The soaking trials followed the manufacturers' specifications of time and temperature. Significant differences in flexural strength were found only among the tested acrylic resins. QC-20 showed the lowest values, while Lucitone 550 and Triplex did not differ statistically. These results might be due to variations in the composition of the resins and in their polymerization cycles. QC-20 is a rapid-heat-polymerized material containing a chemical activator in the monomer formulation. This activator reacts with the initiator in the powder, consuming it and reducing its availability, in such a way that polymerization of the monomer is less efficient and residual monomer is left (18). Another factor that might explain the difference is the cycle of this resin, which requires the shortest time in boiling water for polymerization. Short polymerizing cycles may lead to higher levels of residual monomer (19). Mechanical properties might be adversely affected by high levels of residual monomer (12) because of a plasticizing effect of the monomer, which reduces interchain forces and yields easier deformation under load (20). This could possibly explain QC-20 low flexural strength.

The findings of this study are consistent with those of previous investigations that pointed out that the correct use of chemical cleansers is not associated to alterations in mechanical properties of denture base materials $(9-12,14)$.

Color alterations can be objectively measured using a spectrophotometer. However, a consensus has not yet been reached regarding the exact value of color difference measured by spectrophotometry that corresponds to a clinically relevant difference (15-17). In this study, color alterations were evaluated only by visual examination because clinically perceptible alterations were considered to be more important than a measurable value corresponding to color change. After a soaking cycle simulating 30 days of immersion in the cleansers, the tested acrylic resins did not show any noticeable color change with use of the chemical agents.

The denture cleansers tested in this study were used according to the manufacturers' instructions and did not cause the whitening effect observed in some dentures soaked in chemical solutions. These findings are consistent with those of previous investigations, which attributed the whitening effect on chemically cleansed acrylic resin denture bases to the excessively high temperature of the water rather than to the denture cleanser itself $(9-12,14)$.

Ünlu et al. (13) have found different results from ours and reported significant color alterations after use of denture cleansing agents. These differences are related to the methodology of their study that measured objectively the color values of the specimens using a reflectometer. This device detects color differences that the human eye cannot perceive, which explains the different outcomes of both studies.

Impact strength of the resins submitted to similar conditions will be assessed in a further study.

The findings of this study showed that chemical denture cleansers used according to the manufacturers' specifications did not cause flexural strength alterations 
or color changes in heat-polymerized acrylic resins submitted to soaking cycles simulating 30 days of use.

\section{RESUMO}

O objetivo deste estudo foi avaliar a resistência à flexão e alterações de cor de resinas acrílicas termopolimerizáveis imersas em higienizadores de prótese por diferentes períodos de tempo. Corpos-de-prova retangulares $(65 \times 10 \times 3 \mathrm{~mm})$ de três resinas acrílicas (Lucitone 550, QC-20 e Triplex) foram divididos em três grupos de higienizadores de prótese (Bony Plus, Corega Tabs e Efferdent Plus) e um grupo controle (imersão em água). Foram realizadas imersões por 15 min e 8 horas, simulando 30 dias de uso. O teste de resistência à flexão foi realizado com 105 corposde-prova em máquina de ensaios universais. Alterações de cor foram avaliadas por meio de fotografias tiradas de 21 corpos-deprova. Os resultados de resistência à flexão (em MPa) foram submetidos à análise de variância e teste de Tukey, com nível de significância de 5\%. Houve diferenças significantes $(\mathrm{p}<0.01)$ entre as resinas Lucitone (89,439 \pm 7,962); Triplex (88,024 \pm $5,167)$ and QC-20 (83,379 $\pm 7,153)$. Não foram encontradas diferenças significantes ( $\mathrm{p}>0.05$ ) entre os higienizadores de prótese (Bony Plus = 87,693 \pm 6,943; Corega Tabs = 86,955 \pm 7,114; Efferdent Plus $=86,195 \pm$ 7,865; e controle $=86,536 \pm 7.012$ ) nem entre os períodos de imersão ( $15 \mathrm{~min}=86,875 \pm 7,625$ e $8 \mathrm{~h}$ $=87,432 \pm 7,355$ ) durante os ciclos de imersão que simularam 30 dias de uso. A inspeção visual não detectou qualquer alteração de cor. Os achados desse estudo revelaram que os higienizadores de prótese, quando usados de acordo com as instruções dos fabricantes, não afetaram a resistência à flexão nem causaram alterações de cor nas resinas acrílicas termopolimerizáveis após um período de uso simulado de 30 dias.

\section{REFERENCES}

1. Jagger DC, Harrison A. Denture cleansing - the best approach. Br Dent J 1995;178:413-417.

2. Nikawa H, Yamamoto T, Hamada T, Sadamori S, Agrawal S. Cleansing efficacy of commercial denture cleansers: Ability to reduce Candida albicans biofilm activity. Int J Prosthodont 1995;8:527-534.

3. Webb BC, Thomas CJ, Harty DW, Willcox MD. Effectiveness of two methods of denture sterilization. J Oral Rehabil 1998;25:416-423.

4. Jagger DC, Al-Akhazam L, Harrison A, Rees JS. The effectiveness of seven denture cleansers on tea stain removal from PMMA acrylic resin. Int J Prosthodont 2002;15:549552.

5. Odman PA. The effectiveness of an enzyme-containing denture cleanser. Quintessence Int 1992;23:187-190.

6. McCabe JF, Murray ID, Kelly PJ. The efficacy of denture cleansers. Eur J Prosthodont Restorative Dent 1995;3:203207.

7. Gornitsky M, ParadisI I, Landaverde G, Malo AM, Velly AM. A clinical and microbiological evaluation of denture cleansers for geriatric patients in long-term care institutions. J Can Dent Assoc 2002;68:39-45.

8. Nikawa H, Hamada T, Yamashiro H, Kumagai H. A review of in vitro and in vivo methods to evaluate the efficacy o denture cleansers. Int J Prosthodont 1999;12:153-159.

9. Crawford CA, Lloyd CH, Newton JP, Yemm R. Denture bleaching: a laboratory simulation of patients' cleaning procedures. J Dent 1986;14:258-261.

10. Robinson JG, McCabe JF, Storer R. Denture bases: the effects of various treatments on clarity, strength and structure. J Dent 1987;15:159-165.

11. Arab J, Newton JP, Lloyd CH. The importance of water temperature in denture cleaning procedures. J Dent 1988;16:277-281.

12. Arab J, Newton JP, Lloyd CH. The effect of an elevated level of residual monomer on the whitening of a denture base and its physical properties. J Dent 1989;17:189-194.

13. Ünlü A, Altay OT, Sahmali S. The role of denture cleansers on the whitening of acrylic resins. Int $\mathrm{J}$ Prosthodont 1996;9:266-270.

14. Robinson JG, McCabe JF, Storer R. The whitening of acrylic dentures: the role of denture cleansers. $\mathrm{Br}$ Dent $\mathrm{J}$ 1985;159:247-250.

15. Cook WD and Chong MP. Color stability and visual perception of dimethacrylate based dental composite resins. Biomaterials 1985;6:257-264.

16. Ruyter IE, Nilner K and Möller B. Color stability of dental composite resins materials for crown and bridge veneers. Dent Mater 1987;3:246-251.

17. Seghi RR, Hewlett ER and Kim J. Visual and instrumental colorimetric assessments of small color differences on translucent dental porcelain. J Dent Res 1989;68:1760-1764.

18. Jerolimov V, Brooks SC, Huggett R and Bates JF. Rapid curing of acrylic denture-base materials. Dent Mat 1989;5:18-22.

19. Austin AT and Basker RM. Residual monomer levels in denture bases - the effects of varying short curing cycles. $\mathrm{Br}$ Dent J 1982;153:424-426.

20. Jagger RG. Effect of curing cycle on some properties of a polymethylmethacrylate denture base material. J Oral Rehabil 1978;5:151-157. 